\title{
Transportation Accessibility Benefit and the Dynamic Pattern of Real Estate Prices: Emerging Literature
}

\author{
Aliyu Ahmad Aliyu ${ }^{1}$, Olurotimi Adebowale Kemiki ${ }^{2}$, Muhammad Umar Bello ${ }^{1}$
}

${ }^{1}$ Abubakar Tafawa Balewa University

P. M. B. 0248, Bauchi, Bauchi State, Nigeria

${ }^{2}$ Federal University of Technology Minna

P. M. B. 65, Minna, Nigeria

DOI: $10.22178 /$ pos. $40-5$

JEL Classification: R33, R42

Received 28.10.2018

Accepted 20.11.2018

Published online 30.11.2018

Corresponding Author:

Aliyu Ahmad Aliyu

aliyu1978aa@gmail.com

(c) 2018 The Authors. This

article is licensed under a

Creative Commons

Attribution 4.0 License

(a) (1)

\begin{abstract}
Location preference is a repeatedly debated subject in urban land economics. By and large, these deliberations are either empirical or theoretical in nature. A sizeable number of the previous studies tackle the question of most favorable location provisional on a certain set of constrictions. Moreover, other studies are dedicated to elucidating the nature (worth) of a real property at a particular location. Nevertheless, the problem of ascertaining the indicators that influence real property price is general to both sets of studies. The current body of knowledge on the impact of transportation infrastructure on real estate prices is diverse in its outcome and result with particular reference to degree or extent of impact as well as bearing, ranging from a negative to an unimportant or a positive effect. On the literature results, multiple spatial lag variables were found to be statistically significant signifying that a number of features or attributes of adjoining residential accommodations have significant influence on the subject residential property's value. Whereas the largest part of earlier hedonic price empirical studies considered only selected factors (such as, positive as well as negative impacts of single transportation mode or means, positive or else negative impacts of multiple transportation modes) into account, the majority of recent empirical studies, however, considered all these key determinants, factors and indicators into consideration for analyzing joint impacts of transportation facility. Through considerable strategy, policy in addition to planning or forecasting implications underlying the association between transit oriented developments and real estate values and the difference between previous studies' outcomes and results, there is a strong necessity and requirement for further study and analysis to ascertain an advanced, reliable in addition to dependable level of conclusiveness.
\end{abstract}

Keywords: Accessibility; Land Price; Location; Property Value and Transportation Facility.

\section{INTRODUCTION}

It has been established that positive alongside negative impacts of transportation facility provide virtual benefits as well as negative consequences for dissimilar types of real property at various and strategic distances starting from the nodes and links of diverse forms of transportation routes. Moreover, all things being equal, taking into account these relative merits and demerits, the locations and siting of socioeconomic activities might perhaps shift. Changes of land use in addition to urban formation possibly will follow and prices of the real property could change consequently [69].
In the word of $\mathrm{H}$. Zhong and W. Li [80], transport facilities provide public advantages such as emissions lessening, overcrowding relief, economic growth, and societal equity enhancement. Therefore, enhancing and intensifying transportation systems have been receiving great attention in many urban areas [61]. In order to give a good reason for their venture, successive governments in many cities frequently transport infrastructure can possibly benefit real estate price, and as eventually, may perhaps opt value capture as one of the economic means $[9,56]$. On the other hand, previous studies are still disconcerted concerning the impact of transport accessibility on housing prices. Several types of research have 
established that transport facility enhanced real estate values [2, 47]. However, other previous studies have uncovered negative effects [23, 77].

The varied research outcomes might perhaps be, to a certain extent, due to dissimilar sociodemographic in addition to land use perspectives, over and above model, evaluation preconceived notion [25, 45, 56]. For the reason that past hedonic studies on transportation accessibility benefit largely relied on Ordinary Least Squares (OLS) regression. The appraisals were aptly biased owing to scarcity and deficiency in control for the spatial dependence result, which disclosed a multifaceted and entwined association in the midst of home transactions. For instance, T. Kuethe [44] established that land use variation had a positive effect on home prices by means of an OLS model, while such an effect became statistically non-significant following control of the spatial dependence outcome [80].

Despite the fact that the community advantages of transport facility might perhaps appear apparently understandable, the positioning of transitoriented development can equally have indecisive outcomes on the economic worth of commercial alongside residential developments, particularly when the explicit location in addition to accurate distance are well taken into account. As revealed by B. Ferguson, M. Goldberg, and J. Mark [30], variations in location, as well as transportation, can have effects on metropolitan land and housing markets, together with both value effects along with land use effects [66].

The effect of transport facility on housing values has been investigated by scholars from numerous standpoints, involving diverse types of systems (such as commuter, rapid, light rail and heavy rail), commercial versus residential property. There are other studies that have tried to separate both positive and negative impacts [12]. The research outcomes from these different studies have fashioned opposing results, prompting scholars to keep on investigating the subject matter [66].

The dwelling categories incorporated in these previous studies are residential (single-family, multi-family as well as condominiums) and commercial. Some of the findings revealed a positive association between closeness to transport facility and housing value. Additionally, there is minute substantiation that put forward that nearness to transit service essentially reduce housing price, even though implications for fur- ther investigation by many studies embrace the incorporation of important variables external to transit station closeness, the implication of findings, and definiteness of results [66].

It is imperative to further review past studies on the impact of transport facilities' positioning on adjoining housing prices because scholars up till now did not reach a consensus on how the siting of transport-oriented development influence property worth, including whether the transport facilities enhance or reduce housing value. The fraction of this uncertainty and ambiguity is due to the different unidentified externalities that are connected with the association of closeness. In addition, the latest trends in land use, as well as associated environmental concerns, have eventually led to national strategy and regional models that encourage transport oriented facilities [66].

\section{Transportation and Accessibility Models}

In the words of E. Campbell [13], the proponents of transit economic theory advocate that nearness to public transport facilities is capitalized into real estate values [77]. B. Weinstein and T. Clower identify the evolutions of this theory [77]. All the way through 1960, significant consideration was given on the relatively extensive issue of how transport service affects the urban structure and, thus, urban real estate prices [3, $55,58]$.

The thrust of those studies was the idea that urban real estate prices are affected by convenience, accessibility, and location which were examined generally as the straight-line distance of a particular property from the inner-city or city center [42]. To sum it up, any considerable enhancement or upgrading in the transport facility which improves ease of access and decrease transport expenditure ought to be capitalized in real estate prices and this eventually ushers in land-use alterations. Certainly, this capitalized or analyzed value can give a promising measure of the value or worth of such access [23]. However, it is easier said than done to estimate the impact of accessibility or convenience on real estate prices as the distance is frequently used as a proxy. Yet, distance is not an exact, precise and correct proxy for proximity because of other influences on real estate value [13].

As a matter of fact, the theoretical foundation of previous studies in quest of realizing how trans- 
port infrastructure influences real property values has tremendously been the spatial equilibrium model developed and invented by W. Alonso [3], R. Muth [58], and E. Mills [55] which is sometimes regarded as the AlonsoMuth-Mills (AMM) model. The model centers on the location choices and decisions households and firms. Firms look for locations that maximize profit, yield, revenue or turnover by reducing and lessening transport expenditure. For example, it has been theorized that retail firms ought to locate and situate in the downtown, central business district (CBD) or city center owing to its high degree of ease of access and convenience. Households or family, alternatively, ought to make the best use of satisfaction derived in a trade-off involving two factors: transport expenses and land rent or household consumption and spending [38].

In other words, W. Alonso [3] extended the Von Thunen's theory [72] of agricultural land rent in his book Location and Land Use and eventually placed it in an urban perspective. The central market town in the Von Thunen's model is taken to mean by Alonso as a metropolis with a Central Business District (CBD) in the city center or downtown. Households or family must travel there for them to work in the CBD. Once more, transportation expenditures are regarded as the major explanatory or determining factor in the location choice and decision of households and enterprises or firms.

As established by W. Alonso, a household is theoretical and hypothetically supposed to expend its income on three things: 1) land, 2) transportation or commuter costs and 3) all other goods. The household needs a location in a simplified city which should be monocentric, homogenous, uniform and of which markets are viable and competitive. Employments, goods, in addition to services, are only obtainable in the city center or downtown. For an individual family unit, the prices of land are specified. Land prices are thought, believed and supposed to diminished and reduced with increasing and growing distance from the central business district or city center, which is fundamentally true for the majority of cities and a condition as well as a necessity for market equilibrium as a matter of fact.

Accordingly, a household has to make a decision on how much of its earnings will be exhausted on land, how much on transport costs, and how much on other goods needed. This judgment is affected by the size of a land parcel that can be purchased for a certain financial plan at a definite distance from the city center or downtown. A household can rent a bigger house (on a larger parcel) further away from the downtown or city center for the equivalent budget as a smaller dwelling in close proximity to the city center. But the bigger home at a larger distance from the city center has the difficulty, drawback, and shortcoming of providing higher transportation (Travelling or commuting) costs. This thought is integrated into Alonso's a bid-rent price curve of a household or family unit as a matter of fact.

This is the set of prices for land the individual may perhaps pay at different distances whilst deriving a constant and the same level of satisfaction and utility. The rental fee is paid to propertyowners or landlords who are termed, local monopolists. The landlords are trying to maximize their rents or profits that they receive from the tenants The bidding practice invariably culminates to an inert or static equilibrium, in which the bid rent function turns out to be the rent curve. This so-called bid-rent function approach currently forms the basis and foundation of all modern-day theories and postulations on land use along with land values.

The model is certainly a notion, though, idea, the concept as well as the abstraction of the indicators that influence the location of people and firms. However, through its center of attention on variations in bid-rent ascribed to changes in commuting, transportation or traveling cost, the Alonso-Muth-Mills (AMM) model provides a solid foundation on which to study effects of transportation accessibility on land and real estate values. By providing an increase in ease of access and a decrease in commuting costs, the opening and establishment of new transport infrastructure ought to produce a locational benefit for land proximate to such transport facility, making people as well as firms to outbid one another for convenience and ease of access, which could be revealed in a localized bid-rent surface that peaks at transport facility [38].

\section{Transport Infrastructure and Housing Prices}

It has been established through the findings of previous studies that transportation facility in cities and metropolises has a tremendously positive influence on socioeconomic day-to-day activities as well as lives of individuals, real estate prices and urban land use. Land and landed 
property values are responsive to investment of transport facility such as highway as well as light rail transit-oriented development for the reason that transport or commuting venture enhances convenience and ease of access of close by houses, which is capitalized and calculated in real estate values as established by classical urban land economics' models [3, 72, 75]. However, transport facility does not, at all times, produce positive impacts; it equally generates and produces nuisance effects, for example, traffic noise along with air pollution as the case may be [68].

Nuisance problems have been established to have a negative or disamenity effect on real estate prices. Furthermore, condition, availability, quality, and state of repairs of transport a facility may perhaps also have an effect on real estate values along the transport set of connections, for instance, by means of lowering noise or else enhancing the aesthetic quality of the environs. Several empirical and pragmatic studies have been conducted to determine the influence of commuting facility on real property prices [70]. For instance, hedonic price models by means of multiple regressions are a commonly used and authoritative analysis method for land-use effects [68].

The main concern of earlier studies has differed by the dependent variables employed (such as residential or else commercial property values), the type or mode of transportation (such as water, airport, arterial road, highway, or transit rail), and nearness to network nodes as well as the connections or links. For example, various studies analyzed only nuisance negative consequence (such as air along with noise effluence) of highway or arterial network in addition to rail transit, while others measured positive impacts (such as location, accessibility, and convenience) of highway or arterial network as well as transit rail.

A number of earlier empirical studies analyzed both ease of access or convenience and nuisance or irritation effects of the highway as well as transit rail. Numerous studies employed Euclidean distance to analyze ease of access or else nuisance effects. In addition, a number of studies employed a single buffer or bumper amidst transport facility to evaluate and determine where the impacts may be experienced, while others incorporated manifold distance bands to analyze the decay or rot of impacts. A small number of studies employed an association, configuration, as well as the pattern or noise barriers of the transport corridor in their analysis, despite the fact that the majority of highways or arterial road networks contained by built-up and municipal areas have suspension bridges, underpasses, as well as noise barriers [68].

K. Seo [68] stated that, to the best of his knowledge, no any empirical study has been conducted and published in a reputable and peer-reviewed academic journal that has analyzed the association between arterial road network pavement conditions along with real property values. The author further added that, despite the fact that spatial dependences in the well-known hedonic price models are usual and may perhaps lead to biased and contradictory analyses if ignored [4], merely only a few recent studies incorporated this in their analysis. He concluded that to uncover the positive as well as negative effects of transport infrastructure on real prices over space, a researcher should unite all of the main indicators into a single model for discovering the variables of most relevant.

For example, a research should incorporate both transportation modes in his analysis so as to avert and thwart omitted variable predisposition [25]. The same standard should be taken into account for both ease of access as well as nuisance influences of transport infrastructure with the purpose of obtaining impartial, neutral and imbalanced assessment and measurements [59]. Additionally, accessibility or else nuisance impacts on both residential along with commercial property markets may perhaps vary with regard to geographical coverage and level or degree of distance crumble. Moreover, explanatory variables, which give details on real property prices of apiece market, may possibly vary as well [69].

Consequently, a market-specific in addition to spatially disaggregated strategy ought to be incorporated. Furthermore, it should equally be worth exploring how road network pavement condition and quality, which is investigated and measured for arterial as well as a connection or linking roads for administrative purpose, influence real estate values alongside the corridor. By the way, many cities and urban areas in most developed countries are well-fitted case study areas to verify and confirm the models for joint effects of arterial road networks, highways as well as transit rail stations on residential along with commercial property price. This is for the mere reason that multiple forms of transport facility (such as highways, arterial road network, airports, seas ports, and transit rail station) exist [69]. 


\section{Rail Transit Station and Adjoining Real Estate Prices}

Many studies have been conducted on the influence of light rail transit on nearby real estate prices. For example, researchers [62] particularly studied the effect of Houston's light rail transit system on close-by real estate values. Through employing a multi-level regression model by means of hierarchical data by the side of two levels (individual housing level along with traffic analysis zone level), the study uncovered that propinquity or nearness to light rail stations as well as bus stops has considerable negative effects on the building structures situated within a quarter mile of rail transit stops.

However, as observed by E. Campbell [13], the effects turn out to be trivial and unimportant connecting a quarter mile and one-mile distance beginning or starting from the rail stops. In general, ease of access to rail transit facility as well as job centers has, to a large extent, less influence on real estate prices than housing characteristics [62]. As established by [34], an assortment of studies has revealed that rail transit-oriented facilities can have both positive as well as negative effects on close-by real estate values. Certainly, there have been varied, assorted and diverse studies' outcomes concerning the degree, level, and scope to which light rail transit lines influence real estate prices. It is extremely contextual seeing that the interplay and interaction of numerous variables establish this association or connection [34].

Furthermore, one might hypothetically predict and assume that light rail transit facilities could enhance real estate values provided that government improves riders' convenience and ease of access to workplaces as well as recreational area or parks. It is essential to state that numerous studies have confirmed and discovered this postulation to be correct and factual. Alternatively, when light rail lines produced unwanted pollution as well as crime, they may perhaps be discovered to have a lessening, declining and diminishing the impact on real estate prices.

Table 1 below presents the major outcomes of a number of pertinent studies that have estimated and measured the influence of rail transit facilities on real estate values. Out of the eighteen studies reviewed in the table below by E. Campbell [13] in his paper, twelve established and revealed merely positive effects of rail transit facilities on real estate prices. However, five revealed either mixed (assorted) or insignificant (trivial) outcomes, while only one uncovered negative impacts.

Based on the above findings of previous studies, it came to limelight that most of the past empirical studies revealed positive effects on the value or price of real estate situated and positioned in close proximity to transit rail facilities, particularly for low-income, multi-family as well as commercial developments; further positive influence was found outside the vicinity of the immediate nuisance neighborhood; however, several studies eventually revealed negative effects as rightly observed by E. Campbell [13]. Moreover, it is imperative to have it in mind that the consequential impacts differ, since they are greatly dependent on each study's meticulous data set, perspective and methodology or approach.

\section{Impact of Transit-Oriented Developments on Property Values in Selected European and Asian Countries}

S. Mathur and C. Ferrell [53] as reported by H. Zhong and W. Li [80] discovered no expected and projected capitalization prior to the transit rail facility's establishment. They equally uncovered that positive real estate price impacts emanated barely for the period of transport infrastructure construction and subsequent to the construction. Single-family home prices, particularly in middle-income counties, frequently respond negatively or else neutrally to transit rail ease of access [17]. Conversely, ease of access to transit rail facilities can be capitalized at a higher degree for multi-family residential houses compare to single-family residential accommodations $[17,19]$.

It is worthy to note that, just as in the metaanalyses conducted by [24] as well as [56, 80] findings confirm and validate the above assertion that transit rail facilities affect real estate prices in both positive as well as negative ways and at different magnitudes and degree. It should be noted that these outcomes may perhaps be accredited to an assortment of contexts, various transit rail facilities, landed property forms and dissimilar methods. A good number of preceding and earlier empirical studies reported positive real estate value effects of rail transit facilities and several of them depended on advanced methods of analyzing data. Academic credit deserves to be given to such academic papers written by $[8,11,19]$. Others are $[28,37,63,64,26]$ as they contributed immensely on the subject matter. 
Table 1 - Summary of Studies on Rail Transit's Impacts on Real Estate Prices [13]

\begin{tabular}{|c|c|c|c|c|c|}
\hline No & Authors & Study Area & Transit Rail Type & Effects of Transit Rail Systems on Real Estate Prices & $\begin{array}{l}\text { Effect } \\
(+/-)\end{array}$ \\
\hline 1 & $\begin{array}{l}\text { Al-Mosaind, M. A., Dueker, K. J. } \\
\text { \& Strathman, J. G. (1993) }\end{array}$ & Portland, Oregon & Light Rail & Positive capitalization of proximity to LRT stations & + \\
\hline 2 & Pan, Q. (2012) & Houston, Texas & Light Rail & $\begin{array}{l}\text { Negative effects within a quarter mile of rail stops. Accessibility to transit } \\
\text { and jobs has much less impact on property values than home characteristics }\end{array}$ & - \\
\hline 3 & $\begin{array}{l}\text { Landis, J., Guhathakurta, S. \& } \\
\text { Zhang, M. (1995). }\end{array}$ & San Francisco & $\begin{array}{l}\text { Heavy Rail, Light } \\
\text { Rail, and } \\
\text { Commuter Rail } \\
\end{array}$ & Minor positive capitalization on home sales & + \\
\hline 4 & Ryan, S. (2005) & San Diego, California & Light Rail & Insignificant effect & $\mathrm{X}$ \\
\hline 5 & $\begin{array}{l}\text { Lewis-Workman, S., \& Brod, D. } \\
\text { (1997) }\end{array}$ & $\begin{array}{l}\text { San Francisco, California; } \\
\text { Portland, Oregon }\end{array}$ & Light Rail & $\begin{array}{l}\text { Negative effects near transit stations and positive effects further away. } \\
\text { Findings attributed to negative environmental effects generated by transit } \\
\text { facilities }\end{array}$ & $+/-$ \\
\hline 6 & $\begin{array}{l}\text { Chen, H., Rufulo, A. \& Dueker, K. } \\
\text { (1998) }\end{array}$ & Portland, Oregon & Light Rail & Small net positive effect & + \\
\hline 7 & $\begin{array}{l}\text { Bowes, D. R., \& Ihlanfeldt, K. R. } \\
\text { (2001) }\end{array}$ & Atlanta, Georgia & Heavy Rail & $\begin{array}{l}\text { Large positive effects in high income neighbourhoods between one quarter } \\
\text { and three miles of a station, negative direct effects beyond one quarter mile } \\
\text { to low income neighbourhoods, and negative crime effects in downtown }\end{array}$ & $+/-$ \\
\hline 8 & $\begin{array}{l}\text { Lewis-Workman, S., \& Brod, D. } \\
\text { (1997) }\end{array}$ & $\begin{array}{l}\text { New York City, New } \\
\text { York }\end{array}$ & Light Rail & $\begin{array}{l}\text { Significant positive effects in walking distance to rail station in New York } \\
\text { City }\end{array}$ & + \\
\hline 9 & $\begin{array}{l}\text { Hess, D. B., \& Almeida, T. M. } \\
(2007)\end{array}$ & Buffalo, New York & Light Rail & $\begin{array}{l}\text { Positive in high-income station areas and negative in low-income station } \\
\text { areas }\end{array}$ & $+/-$ \\
\hline 10 & Voith, R. (1991) & $\begin{array}{l}\text { New Jersey; } \\
\text { Philadelphia, } \\
\text { Pennsylvania }\end{array}$ & Commuter Rail & Minor positive effects & + \\
\hline 11 & Armstrong, R. J. Jr. (1994) & Boston, Massachusetts & Commuter Rail & Significant positive impacts & + \\
\hline 12 & $\begin{array}{l}\text { Gatzlaff, D. H., \& Smith, M. T. } \\
\text { (1993) }\end{array}$ & Miami, Florida & Heavy Rail & Weak impact of system. Higher positive effects in high priced neighborhood & + \\
\hline 13 & Haider, M., \& Miller, E. J. (2000) & Toronto, Canada & Heavy Rail & $\begin{array}{l}\text { Positive but not as strong as other factors, like neighborhood characteristics } \\
\text { and structural attributes. }\end{array}$ & + \\
\hline 14 & $\begin{array}{l}\text { Cervero, R. \& Aschauer, D. } \\
\text { (1998) }\end{array}$ & San Francisco, California & Heavy Rail & Positive effect increased rent within a quarter mile of the stations & + \\
\hline 15 & $\begin{array}{l}\text { Nelson, A., \& McCleskey, S. } \\
(1992)\end{array}$ & Atlanta, Georgia & Heavy Rail & $\begin{array}{l}\text { Positive effects on low income neighborhood but negative effects on high } \\
\text { income communities }\end{array}$ & $+/-$ \\
\hline 16 & Weinberger, R. R. (2001) & $\begin{array}{l}\text { Santa Clara County, } \\
\text { California }\end{array}$ & Light Rail & $\begin{array}{l}\text { Positive effects on properties within } 0.25 \text { miles of a station, even more } \\
\text { positive effect on properties within } 0.25 \text { and } 0.5 \text { miles of a station }\end{array}$ & + \\
\hline 17 & Cervero, R. \& Duncan, B. (2002) & $\begin{array}{l}\text { Santa Clara County, } \\
\text { California }\end{array}$ & $\begin{array}{l}\text { Light Rail and } \\
\text { Commuter Rail }\end{array}$ & Substantial positive effects on commercial properties & + \\
\hline 18 & $\begin{array}{l}\text { Armstrong, R. J., \& Rodríguez, D. } \\
\text { A. (2006) }\end{array}$ & Boston, Massachusetts & Commuter Rail & Positive capitalization of proximity to LRT stations & + \\
\hline
\end{tabular}


In another study, [1] as asserted by [80] examined the likely capitalization of the transit facility in Santiago, Chile and found a positive relationship. Researchers [80] established that the influence of rail transit facilities on proximate housing prices was negative prior to the establishment of the facility, but eventually moved to positive in the operational and use stage. On the contrary, authors [43] reported that accommodations in the surrounding area of transit-oriented developments may perhaps before now have higher prices and values prior to the opening of a transit rail facility and asserted that the premium for the nearness to transit rail facilities may be connected to other location and accessibility indicators as a matter of fact.

Furthermore, according to $\mathrm{H}$. Zhong and W. Li [80], a bunch of empirical studies carried out in Asian urban areas such as Bangkok in Thailand [22], Seoul in Korea [20], Beijing in China [79] and Shanghai in China also [64], revealed positive influences on real estate prices. Scholars have as well found positive effects in European nations and metropolises, such as Helsinki in Finland [46], London in the UK [33] and the Netherlands [24].

Looking at the aforementioned findings from previous studies, H. Zhong and W. Li [80] argued that the impacts were, by and large, more evident in European as well as Asian urban areas, where convenience and ease of access to private transportation or commuting is more restricted and transit-oriented traditions are more patronized $[24,56,57]$. Nevertheless, transit rail facility impacts on real estate prices may perhaps differ, largely depending on forms of technology, development phases, real estate markets as well as land-use feature proximate to the rail transit station areas.

For instance, rail transit facilities can be either light rail transit (LRT) or else heavy rail transit (HRT); these two forms of transit systems vary with respect to construction cost as well as carrying or haulage capacity, except their land use repercussion and connotation have not been well examined in the existing literature [79]. Although, authors [21] uncovered no significant level of land value changes and variations connected with the transit facility in San Francisco following 20 years of operation, a good number of preceding and earlier studies validated that transit could have a number of positive real es- tate value impact as stated by H. Zhong and W. Li [80].

Moreover, multi-family houses usually are usually better aligned with transport-oriented developments decisive factor compares to singlefamily homes. Besides, the impacts may possibly rely on context-specific land use attributes. Capitalization impacts are more often than not connected with trackable residential areas [29], vigorous economies [18], upbeat along with hopeful land use planning $[14,54]$, and land use rise and expansion along the transit facilities [20], mainly for residential uses. H. Du and C. Mulley [27] discovered significant variations (starting from $42 \%$ to $50 \%$ ) depending on location or accessibility in England. Authors [15], as well as D. Bowes and K. Ihlanfeldt [11], equally reported huge variations in their San Diego and Atlanta case studies, correspondingly. With reference to developing, emerging or third world countries, scholars have discovered significant magnitudes along with larger catchment neighborhoods of public transit facilities $[40,78]$.

On the other hand, there is no generally accepted consensus concerning how the above determinants affect residents' choice and preferences toward the rail transit facilities. Furthermore, a good number of earlier studies incorporated the Ordinary Least Squares regression approach or technique. Their analyses and assessments may perhaps be relatively biased, conflicting, inconsistent and contradictory owing to the lack of control designed for the spatial dependence outcome [39].

In the words of L. Anselin [4] as pointed out by H. Zhong and W. Li [80], such an impact examines the association sandwiched between the price of a residential accommodation and the price in addition to various features of close-by properties. Past scholars, such as W. Li and J.-D. Saphores [52] and C. Redfearn [65], have elaborated on this subject in their empirical studies. In a multifaceted and multifarious urban real estate market, such a spatial association violates a fundamental postulation of linear regression, that observations are independent and free from one another [49]. Many spatial regression methods and approaches [48] have been developed and introduced to address this matter [50]. Table 2 below presents empirical studies on transitoriented development's effects on real estate prices. 
Table 2 - Transit Oriented Development Empirical Studies [66]

\begin{tabular}{|c|c|c|c|c|c|c|}
\hline No & $\begin{array}{l}\text { Author(s) } \\
\text { (Year } \\
\text { Published) }\end{array}$ & $\begin{array}{l}\text { City/Region(s) } \\
\text { (Transit System) }\end{array}$ & $\begin{array}{l}\text { Type of } \\
\text { Property } \\
\text { Studied }\end{array}$ & Sample Characteristics & Methods & Research Findings \\
\hline 1 & $\begin{array}{l}\text { Grass, R. G. } \\
(1992)\end{array}$ & $\begin{array}{l}\text { Washington, D.C. } \\
\text { (METRO Metrorail) }\end{array}$ & Residential & $\begin{array}{l}\text { Parcel regression }=6,004 \\
\text { observations, Level regression }=9 \\
\text { observations }\end{array}$ & $\begin{array}{l}\text { Hedonic price } \\
\text { equation (HPE) } \\
\text { and Ordinary Least } \\
\text { Squares (OLS) }\end{array}$ & $\begin{array}{l}\text { Metro station openings cause residential property } \\
\text { values to rise by } \$ 1,827 \text { in adjacent areas. }\end{array}$ \\
\hline 2 & $\begin{array}{l}\text { Gatzlaff, D. H., } \\
\& \text { Smith, M. T. } \\
\text { (1993) }\end{array}$ & $\begin{array}{l}\text { Miami, Florida (Miami } \\
\text { Metrorail) }\end{array}$ & Residential & $\begin{array}{l}912 \text { single-family detached } \\
\text { residential properties }\end{array}$ & $\begin{array}{l}\text { Hedonic price } \\
\text { models }\end{array}$ & $\begin{array}{l}\text { Found weak evidence that there was any major effect } \\
\text { to residential values due to announcement of the } \\
\text { development of the Miami Metrorail. }\end{array}$ \\
\hline 3 & $\begin{array}{l}\text { Hess, D. B., \& } \\
\text { Almeida, T. M. } \\
(2007)\end{array}$ & $\begin{array}{l}\text { Buffalo, New York } \\
\text { (Metro Rail) }\end{array}$ & Residential & $\begin{array}{l}2002 \text { assessed value for } 7,357 \\
\text { residential properties }\end{array}$ & $\begin{array}{l}\text { Regression model } \\
\text { of annual repeat } \\
\text { sales }\end{array}$ & $\begin{array}{l}\text { All Stations Model revealed that, throughout the } \\
\text { system, a typical home located within one-quarter of } \\
\text { a mile of a rail station could earn a premium of } \\
\$ 1,300-\$ 3,000 \text { to the median home value of } \$ 59,300 \text {. } \\
\text { Individual Stations Model indicated that effects were } \\
\text { not felt evenly throughout the system. }\end{array}$ \\
\hline 4 & $\begin{array}{l}\text { Chen, H., } \\
\text { Rufulo, A. \& } \\
\text { Dueker, K. } \\
\text { (1998) } \\
\end{array}$ & $\begin{array}{l}\text { Portland, Oregon } \\
\text { (MAX) }\end{array}$ & Residential & $\begin{array}{l}830 \text { single family homes sold } \\
\text { between } 1992 \text { and } 1994\end{array}$ & $\begin{array}{l}\text { Hedonic pricing } \\
\text { model }\end{array}$ & $\begin{array}{l}\text { At } 100 \text { meters ( } 328 \text { feet) away from stations, each } \\
\text { additional meter ( } 3.28 \text { feet) farther away from the } \\
\text { LRT station resulted in a } \$ 32.20 \text { decrease in price for } \\
\text { an average price house at } \$ 85,724\end{array}$ \\
\hline 5 & $\begin{array}{l}\text { Haider, M., \& } \\
\text { Miller, E. J. } \\
(2000)\end{array}$ & $\begin{array}{l}\text { Greater Toronto Area, } \\
\text { Canada (Subway and } \\
\text { Highway) }\end{array}$ & Residential & 27,400 freehold sales during 1995 & $\begin{array}{l}\text { Spatial } \\
\text { autoregressive } \\
\text { (SAR) models }\end{array}$ & $\begin{array}{l}\text { Location and transportation factors were not strong } \\
\text { determinants of housing values. However, proximity } \\
\text { of } 1.5 \mathrm{~km} \text { to a subway added approximately } \$ 4,000 \text { to } \\
\text { property value }\end{array}$ \\
\hline 6 & $\begin{array}{l}\text { Nelson, A. } \\
\text { (1999) }\end{array}$ & \begin{tabular}{|l|} 
Atlanta, Georgia \\
(MARTA Metropolitan \\
Atlanta Rapid Transit \\
Authority) \\
\end{tabular} & Commercial & $\begin{array}{l}30 \text { sales of office commercial } \\
\text { property between } 1980 \text { and } 1994\end{array}$ & $\begin{array}{l}\text { OLS regression } \\
\text { equation }\end{array}$ & $\begin{array}{l}\text { The price per square meter falls by } \$ 75 \text { for each } \\
\text { meter away from the center of transit stations and } \\
\text { rises } \$ 433 \text { for location within SPIDs }\end{array}$ \\
\hline 7 & $\begin{array}{l}\text { Ryan, S. } \\
(2005)\end{array}$ & $\begin{array}{l}\text { San Diego, California } \\
\text { (SDMTS, San Diego } \\
\text { Metropolitan Transit } \\
\text { System) }\end{array}$ & Commercial & $\begin{array}{l}\text { Aggregate office/ industrial } \\
\text { property data for } 3 \text { market areas, } \\
\text { East County }(n=356), \text { South Bay } \\
(\mathrm{n}=103) \text { and Centre City }(\mathrm{n}=1779)\end{array}$ & $\begin{array}{l}\text { Hedonic price } \\
\text { analysis }\end{array}$ & $\begin{array}{l}\text { Proximity to transit stations was not valued by office } \\
\text { firms in any of the three market areas }\end{array}$ \\
\hline 8 & $\begin{array}{l}\text { Bowes, D. R., \& } \\
\text { Ihlanfeldt, K. R. } \\
(2001)\end{array}$ & \begin{tabular}{l|} 
Atlanta, Georgia \\
(MARTA Metropolitan \\
Atlanta Rapid Transit \\
Authority) \\
\end{tabular} & $\begin{array}{l}\text { Residential } \\
\text { and } \\
\text { Commercial }\end{array}$ & Total observations $=22,388$ & $\begin{array}{l}\text { Hedonic and } \\
\text { Auxiliary models }\end{array}$ & $\begin{array}{l}\text { Properties within a quarter-mile from a rail station } \\
\text { were found to sell for } 19 \% \text { less than properties } \\
\text { beyond three miles from a station }\end{array}$ \\
\hline 9 & $\begin{array}{l}\text { Cervero, R. \& } \\
\text { Duncan, B. } \\
(2002)\end{array}$ & $\begin{array}{l}\text { Los Angeles, California } \\
\text { Metro Link } \\
\text { and Metro Rapid } \\
\text { Transit }\end{array}$ & $\begin{array}{l}\text { Residential } \\
\text { and } \\
\text { Commercial }\end{array}$ & $\begin{array}{l}\text { Multi-family = 3,803, Condo } \\
=13,462 \text {, Single-Family =40, 966, } \\
\text { Commercial =1,241 }\end{array}$ & $\begin{array}{l}\text { Hedonic Price } \\
\text { models }\end{array}$ & $\begin{array}{l}\text { For condominiums, the study revealed that if located } \\
\text { near BRT stops, then they generally sold for } 5.1 \% \text { less } \\
\text { Single-family houses mirrored results of } \\
\text { condominiums for the most part, but were } \\
\text { statistically less robust than condominiums. Results } \\
\text { for commercial properties were uneven and unclear. }\end{array}$ \\
\hline
\end{tabular}


In summary, the above empirical studies contribute to literature as well as the policy debate concerning whether nearness to transit-oriented development impacts positively on real estate prices, by exploring and analyzing the following questions. First, is there an urgent requirement to control in favor of the spatial dependence influence to get unprejudiced, unbiased and impartial estimates? Second, does the real estate value effect of transit facility vary as a result of the real estate market type, form, development phase, rail transit technology in addition to proximatestation land use attributes?

To answer the first question, many researchers analyzed and measure spatial regression models along with comparing and matching up the studies' findings and outcomes with those from Ordinary Least Square (OLS) models. To answer and respond to the second question, some scholars estimated and analyzed the models for both multi-families along with single-family markets unconnectedly and independently. They eventually added numerous pertinent interaction terms assumptions and conditions into the models [80].

Even though many scholars have employed hedonic pricing model in their analysis to estimate transit-oriented developments through comparing prices of real properties contained by a certain distance starting from a transit facility in the midst of those further than that distance, the accurateness of these evaluations and estimations is, however, subject to suspicious and doubts owing to methodological limitations and shortcomings. By means of analyzing and estimating single-family as well as multi-family property sale transactions in Los Angeles (CA) during 2003 and 2004, authors [80] observed that the spatial hedonic pricing study examines how the real estate value influences of transit facility can turn out to be unpredictable depending on real estate markets, transit technologies, adjoining-station land uses in addition to transit development stages.

On the contrary, findings emanating from the spatial Durbin models as well as the Geographically Weighted/Subjective Regression models amid those uncovered from the conventional Ordinary Least Squares approach in authors [80] empirical study reveals the assessment and evaluation accuracy can be enhanced significantly by scheming and calculating for the spatial dependence impact/effect.
Nearness to grown-up rail transit developments, by and large, generate benefit to multi-family property prices, except that the impact is negative for single-family residential properties. Occupants (particularly those from single-family homes) appear to put more emphasis to closeness to heavy rail transit-oriented development compare to light rail facilities. The premiums for rail transit ease of access, equally, for the most part, depend on dissimilar development stages and can be greatly discounted by the presence of park-and-ride services [80].

\section{RESULTS AND DISCUSSION}

The previous existing body of knowledge established that ease of access effect for highway exits expand and extend further away from light rail transit-oriented development in the residential model. The highway or artery configuration and design impact on residential property prices confirm and validate that below-grade artery or highways have moderately positive influences on close by homes and apartments weighs against those next to ground level or else above. Furthermore, study outcomes and findings from the association between asphalt road conditions along with residential property prices indicate that there is no considerable effect connecting them.

Several variations in the influence of neighborhood amenities on real estate values came into view involving residential along with commercial property markets. For instance, in the commercial models, the convenience and ease of access effect for highway or artery exits extend below for light rail transit facilities. Although coefficients for short distances (contained by $300 \mathrm{~m}$ ) from arteries or highways and rail light transit facility connections were anticipated to be negative in both residential along with commercial models, only commercial models indicate a considerable negative association [69].

It was equally established through the findings of the literature that dissimilar impacts by network component, mode, as well as distance on commercial submarkets (that is, office, industrial, retail, along with service properties) were subjected into analysis as well and the study outcomes differ based on forms, types, and nature of submarket. Thus, results of three empirical articles confirm and validate that transport ventures or investments more often than not have consid- 
erable effects on land and landed properties either in a positive or otherwise negative way or direction in agreement and accordance with the transport network component, mode as well as distance, despite the fact that impacts for various conditions (that is, nearness to links or connections of highway or artery in addition to light rail transit along with asphalt road or pavement quality) do not considerably, appreciably and drastically alter residential property values [69].

Based on the literature results, multiple spatial lag variables were found to be statistically significant signifying that a number of features or attributes of adjoining residential accommodations have a significant influence on the subject residential property's value. For example, the existence of an additional bathroom, pool as well as the expanded structural area of adjacent residential properties were discovered to be positively influencing the property worth or value of a residential accommodation. In [80] empirical study, they discovered considerable variations between the results. For example, the ordinary least square model reveals that being situated around a quarter mile from an established rail transit facility does not have a considerable effect on the value of multi-family residential unit; however, the spatial model establishes that the overall influence is significant and also its extent, magnitude, and degree is 10 times higher compared to ordinary least square estimation.

Whereas the ordinary least square model indicates a least significant property value effect for single-family homes situated within a quarter mile of a newly opened rail transit facility, the spatial model reports that such an influence is significant and the level, magnitude or extent is equally much higher compare to ordinary least square analysis. Analyses discrepancies between the ordinary least square and the spatial model were as well discovered on a number of other variables, such as nearness to highways, arteries, rail tracks along with bus stops, in addition to crime rates, for both single-family as well as multi-family housing samples [80].

The findings from the literature further revealed that multi-family residential property situated within $400 \mathrm{~m}$ of a planned and the proposed station is more than twofold the value of its equivalent situated further than $1600 \mathrm{~m}$ of the rail transit station. It is worthy to mention that such an impact, which is significantly higher compared to many previous studies [56], indicates that multi- family residential homes are connected with a huge speculative and tentative premium for immediate closeness to a proposed and planned rail transit station [73]. Researchers [80] observed that the positive and optimistic speculative premium are equally experienced and noticeable on the other proximity-based variables $(400-800 \mathrm{~m}$ and $800-1600 \mathrm{~m})$, but, to a large extent, is a lesser magnitude and also not statistically important.

Quite the opposite, [80] uncovered a small speculative premium for the single-family market: the entire three proximity-based variables have negative signs for the single-family market; for instance, a single-family home situated within $400 \mathrm{~m}$ to $800 \mathrm{~m}$ beginning from a proposed rail transit station is $8 \%$ (or $\$ 42,330$ ) cheaper compared to its equivalent situated at least $1600 \mathrm{~m}$ further than the proposed rail transit stations, holding all other variables to be constant.

Weigh against other residential properties situated further than $1600 \mathrm{~m}$ from full-grown rail line stations and holding all other variables to be constant, authors [80] established that the values of single-family residential units within 400-800 $\mathrm{m}$ from the rail transit stations would be considerably lower. Quite the reverse, the multi-family residential market appears to have obtained significant benefits by being proximate to these rail transit stations. Multi-family residential units situated within the three distance bands from grown-up rail stations $(0-400 \mathrm{~m}, 400-800 \mathrm{~m}$ along with 800-1600 m) are 27-99 \% (\$283,090 to $\$ 1,030,410$ ) more expensive and costly compare to their equivalents situated beyond 1600 $\mathrm{m}$. On the other hand, these capitalization consequences lessen and decline significantly when the rail transit station has a park-and-ride accessible. Furthermore, one likely clarification and elucidation is that park-and-ride services are more often than not connected with a number of disadvantages and drawbacks [80].

As observed by [80], earlier empirical studies that solely depend on conventional and modern ordinary least square regressions frequently assert positive value, price or worth premiums for single-family residential units in close proximity to rail transit stations. Their empirical study raises a worry concerning the accuracy and correctness of such earlier studies owing to the deficiency in control for the spatial dependence effect. On the other hand, several preceding empirical studies established negative effects [24] 
for the single-family residential market. For instance, authors [11] revealed that single-family residential units within a quarter mile beginning from rail transit stations in Atlanta sold for $19 \%$ less than residential homes further than three miles. Researchers [56] have shown that people are eager and keen to pay more for a rail transit facility if they dwell in an area with a higher and different transit mode share.

Results from the reviewed literature equally indicate that inhabitants from single-family housing unit in an auto-oriented metropolis might perhaps not consider transit-oriented development as a positive and affirmative amenity; nevertheless, multi-family housing units in Los Angeles appear to put a positive value or price on transit convenience and ease of access. H. Zhong and W. Li's [80] empirical results equally concur with a number of earlier empirical studies that: residential properties in close proximity to walkand-ride stations have larger capitalization advantages compare to those close to park-and-ride stations $[7,8,10,32,41]$. Furthermore, their findings conform to quite a number of earlier empirical studies that: the transit facility is capitalized in a different way between single-family homes and other residential housing markets [7].

\section{CONCLUSIONS}

On the foundation and origin of urban economic theories, postulations, assumptions, prepositions and earlier empirical studies, this article extensively reviews related studies on the effect of transportation investment on adjoining real estate values [73]. Transport venture or investment for pavement situation may perhaps augment, increase and boost positive effects on prices and values of residential accommodations neighbouring enhanced arterial road network, neighbourhood connector, in addition to residential roads owing to the decline, decrease and lessening of noise level along with enhanced aesthetic or visual condition in neighbourhood [68, 70]. Positive effects on real estate values where pavement condition is enhanced by repair or else rehabilitation may possibly increase more than real property values amid bad pavement condition.

Whereas the largest part of earlier hedonic price empirical studies considered only selected factors (such as, positive as well as negative impacts of single transportation mode or means, positive or else negative impacts of multiple transportation modes) into account, the majority of recent empirical studies, however, considered all these key determinants, factors and indicators into consideration for analyzing joint impacts of transportation facility $[68,70]$. In theory, the latest empirical studies unified a number of different and incongruent earlier empirical study outcomes in the hedonic price model literature into a single, wide-ranging, idealized and diagrammatic model integrating nodes and links, arterial road and rail transit, amenities and disamenities in addition to distance decay of all of these impacts [73].

Even though the findings of the majority of these previous empirical studies established some degree of association between transit station positioning and real estate value, an accurate, as well as reliable and dependable correlation connecting and linking the two has, up till now, not established or confirmed. Proving this correlation scientifically is easier said than done in view of the fact that there are quite a lot of contextual and related factors, determinants and indicators to take into account when analyzing and studying a location [66]. These factors include environment, land-use, and type, zoning regulations, neighborhood characteristics, and demographics.

Additionally, the degree, as well as level of the impact of local externalities can equally be difficult, challenging and tough when coming up with a hedonic price model, for the reason that such factors and indicators as residential accommodation characteristics along with value differ or diverge all over regions. Through considerable strategy, policy in addition to planning or forecasting implications underlying the association between transit-oriented developments and real estate values and the difference between previous studies' outcomes and results, there is a strong necessity and requirement for further study and analysis to ascertain an advanced, reliable in addition to dependable level of conclusiveness [66].

The findings from the future studies could be used for city establishments as well as town planners for financial support mechanisms of transport facility or validity of investments and ventures. It could equally be helpful for private real estate developers for maximizing development, returns and profits or for sitting developments $[68,70]$. 


\section{REFERENCES}

1. Agostini, C. A., \& Palmucci, G. A. (2008). The Anticipated Capitalisation Effect of a New Metro Line on Housing Prices. Fiscal Studies, 29(2), 233-256. doi: 10.1111/j.1475-5890.2008.00074.x

2. Al-Mosaind, M. A., Dueker, K. J. \& Strathman, J. G. (1993). Light-Rail Transit Stations and Property Values: A Hedonic Price Approach. Transportation Research Record, 1400, 90-94.

3. Alonso, W. (1977). Location and Land Use: Toward a General Theory of Land Rent. Cambridge: Harvard University Press.

4. Anselin, L. (2010). Spatial Econometrics: Methods and Models. Boston: Kluwer Academic.

5. Armstrong, R. J. Jr. (1994). Impacts of Commuter Rail Service as Reflected in Single-Family Residential Property Values. Transportation Research Record, 1446, 88-98.

6. Armstrong, R. J., \& Rodríguez, D. A. (2006). An Evaluation of the Accessibility Benefits of Commuter Rail in Eastern Massachusetts using Spatial Hedonic Price Functions. Transportation, 33(1), 2143. doi: 10.1007/s11116-005-0949-x

7. Atkinson-Palombo, C. (2010). Comparing the Capitalisation Benefits of Light-rail Transit and Overlay Zoning for Single-family Houses and Condos by Neighbourhood Type in Metropolitan Phoenix, Arizona. Urban Studies, 47(11), 2409-2426. doi: 10.1177/0042098009357963

8. Billings, S. B. (2011). Estimating the value of a new transit option. Regional Science and Urban Economics, 41(6), 525-536. doi: 10.1016/j.regsciurbeco.2011.03.013

9. Boarnet, M. G., Houston, D., \& Spears S. (2013). The Exposition Light Rail Line Study: "Before-After" Opening Travel Impacts and New Resident Sample Preliminary Analysis. Retrieved from https://community-wealth.org/sites/clone.community-wealth.org/files/downloads/paperboarnet.pdf

10. Bollinger, C. R. \& Ihlanfeldt, K. R. (1997). The Impact of Rapid Rail Transit on Economic Development: The Case of Atlanta's MARTA. Journal of Urban Economics, 42(2), 179-204. doi: 10.1006/juec.1996.2020

11. Bowes, D. R., \& Ihlanfeldt, K. R. (2001). Identifying the Impacts of Rail Transit Stations on Residential Property Values. Journal of Urban Economics, 50(1), 1-25. doi: 10.1006/juec.2001.2214

12. Brinckerhoff, P. (2001). The Effect of Rail Transit on Property Values: A Summary of Studies. Retrieved from http://www3.drcog.org/documents/archive/The_effect_of_Rail_Transit_on_Property_Values_Su mmary_of_Studies1.pdf

13. Campbell, E. C. (2011). Light Rail Impacts on Property Values: Analyzing Houston's Metro Rail (Master's thesis). Retrieved from https://repositories.lib.utexas.edu/handle/2152/ETD-UT2011-05-3208

14. Cao, X. (Jason), \& Porter-Nelson, D. (2016). Real estate development in anticipation of the Green Line light rail transit in St. Paul. Transport Policy, 51, 24-32. doi: 10.1016/j.tranpol.2016.01.007

15. Carlton, I., Cervero, R., Rhodes, M. \& Lavine, E. (2012, October 1). Developing and Implementing the City of Los Angeles. Transit Corridors Strategy. Retrieved from https://planning.lacity.org/policyinitiatives/TransitOrientedDistrictPlanning/LATransitCorrido rsStrategy_WhitePaper\%20Final\%20(2012-10-01)\%20Carlton.pdf

16. Cervero, R. \& Aschauer, D. (1998). Economic Impact Analysis of Transit Investments: Guidebook for Practitioners. Retrieved from http://onlinepubs.trb.org/onlinepubs/tcrp/tcrp_rpt_35.pdf

17. Cervero, R. \& Duncan, B. (2002). Land Value Impacts of Rail Transit Services in Los Angles County. Retrieved from https://www.researchgate.net/publication/265150802_Land_Value_Impacts_of_Rail_Transit_Se rvices_in_Los_Angeles_County 
18. Cervero, R. (2006). Transit-Based Housing in San Francisco Bay Area: Market Profiles and Rent Premiums. Transportation Quarterly, 50, 309-333.

19. Cervero, R., \& Duncan, M. (2002). Transit's Value-Added Effects: Light and Commuter Rail Services and Commercial Land Values. Transportation Research Record: Journal of the Transportation Research Board, 1805(1), 8-15. doi: 10.3141/1805-02

20. Cervero, R., \& Kang, C. D. (2011). Bus rapid transit impacts on land uses and land values in Seoul, Korea. Transport Policy, 18(1), 102-116. doi: 10.1016/j.tranpol.2010.06.005

21. Cervero, R., \& Landis, J. (1997). Twenty years of the Bay Area Rapid Transit system: Land use and development impacts. Transportation Research Part A: Policy and Practice, 31(4), 309-333. doi: 10.1016/s0965-8564(96)00027-4

22. Chalermpong, S. (2007). Rail Transit and Residential Land Use in Developing Countries. Transportation Research Record: Journal of the Transportation Research Board, 2038(1), 111119. doi: $10.3141 / 2038-15$

23. Chen, H., Rufulo, A. \& Dueker, K. (1998). Measuring the Impact of Light Rail Systems on SingleFamily Home Prices: A Hedonic Approach with GIS Applications. Center for Urban Studies Publication and Reports, Paper 35. Retrieved from https://pdxscholar.library.pdx.edu/cgi/viewcontent.cgi?article=1034\&context=cus_pubs

24. Debrezion, G., Pels, E., \& Rietveld, P. (2007). The Impact of Railway Stations on Residential and Commercial Property Value: A Meta-analysis. The Journal of Real Estate Finance and Economics, 35(2), 161-180. doi: 10.1007/s11146-007-9032-z

25. Debrezion, G., Pels, E., \& Rietveld, P. (2010). The Impact of Rail Transport on Real Estate Prices. Urban Studies, 48(5), 997-1015. doi: 10.1177/0042098010371395

26. Delmelle, E., Yan, S., \& Duncan, M. (2012). The impact of a new light rail system on single-family property values in Charlotte, North Carolina. Journal of Transport and Land Use, 5(2). doi: 10.5198/jtlu.v5i2.261

27. Du, H. \& Mulley, C. (2007). Transport Accessibility and Land Value: A case Study of Tyne and Wear. Retrieved from http://citeseerx.ist.psu.edu/viewdoc/download?doi=10.1.1.111.4163\&rep=rep1\&type=pdf

28. Duncan, M. (2008). Comparing Rail Transit Capitalization Benefits for Single-Family and Condominium Units in San Diego, California. Transportation Research Record: Journal of the Transportation Research Board, 2067(1), 120-130. doi: 10.3141/2067-14

29. Duncan, M. (2010). The Impact of Transit-oriented Development on Housing Prices in San Diego, CA. Urban Studies, 48(1), 101-127. doi: 10.1177/0042098009359958

30. Ferguson, B. G., Goldberg, M. A. \& Mark, J. (1988). The Pre-Service Impacts of the Vancouver Advanced Light Rail Transit System on Single-Family Property Values. New York: Praeger.

31. Freeman, A. M. (1979). Hedonic Prices, Property Values and Measuring Environmental Benefits: A Survey of the Issues. The Scandinavian Journal of Economics, 81(2), 154. doi: 10.2307/3439957

32. Gatzlaff, D. H., \& Smith, M. T. (1993). The Impact of the Miami Metrorail on the Value of Residences near Station Locations. Land Economics, 69(1), 54. doi: 10.2307/3146278

33. Gibbon, S. \& Machin S. (2003). Rail Access and House Prices: An Evaluation of the Wider Benefits of Transport Improvements. Retrieved from http://eprints.lse.ac.uk/45233

34. Goetz, E.G., Ko, K., Hagar, A., Ton, H. \& Matson, J. (2010). The Hiawatha Line: Impacts on Land Use and Residential Housing Value. Retrieved from http://citeseerx.ist.psu.edu/viewdoc/download?doi=10.1.1.173.3149\&rep=rep1\&type=pdf

35. Grass, R. G. (1992). The estimation of residential property values around transit station sites in Washington, D.C. Journal of Economics and Finance, 16(2), 139-146. doi: 10.1007/bf02920114 
36. Haider, M., \& Miller, E. J. (2000). Effects of Transportation Infrastructure and Location on Residential Real Estate Values: Application of Spatial Autoregressive Techniques. Transportation Research Record: Journal of the Transportation Research Board, 1722(1), 1-8. doi: 10.3141/172201

37. Hess, D. B., \& Almeida, T. M. (2007). Impact of Proximity to Light Rail Rapid Transit on Station-area Property Values in Buffalo, New York. Urban Studies, 44(5-6), 1041-1068. doi: 10.1080/00420980701256005

38. Higgins, C. D. (2015). A Value Planning Framework for Predicting and Recapturing the Value of Rapid Transit Infrastructure (Doctoral dissertation). Retrieved from https://macsphere.mcmaster.ca/bitstream/11375/18280/2/CD\%20Higgins\%20\%20Dissertation.pdf

39. Ibeas, Á., Cordera, R., dell' Olio, L., Coppola, P., \& Dominguez, A. (2012). Modelling transport and real-estate values interactions in urban systems. Journal of Transport Geography, 24, 370-382. doi: 10.1016/j.jtrangeo.2012.04.012

40. Jun, M.-J. (2012). Redistributive effects of bus rapid transit (BRT) on development patterns and property values in Seoul, Korea. Transport Policy, 19(1), 85-92. doi: 10.1016/j.tranpol.2011.09.003

41. Kahn, M. E. (2007). Gentrification Trends in New Transit-Oriented Communities: Evidence from 14 Cities That Expanded and Built Rail Transit Systems. Real Estate Economics, 35(2), 155-182. doi: 10.1111/j.1540-6229.2007.00186.x

42. Kain, J. F., \& Quigley, J. M. (1970). Measuring the Value of Housing Quality. Journal of the American Statistical Association, 65(330), 532. doi: 10.2307/2284565

43. Ko, K. \& Cao, X. J. (2013). Impact of Hiawatha light rail line on commercial and industrial property values in Minneapolis. Retrieved from https://conservancy.umn.edu/bitstream/handle/11299/97674/CTS\%201005.pdf? sequence=1\&isAllowed $=y$

44. Kuethe, T. H. (2012). Spatial Fragmentation and the Value of Residential Housing. Land Economics, 88(1), 16-27.

45. Kuminoff, N. V., Parmeter, C. F., \& Pope, J. C. (2010). Which hedonic models can we trust to recover the marginal willingness to pay for environmental amenities? Journal of Environmental Economics and Management, 60(3), 145-160. doi: 10.1016/j.jeem.2010.06.001

46. Laakso, S. (1992). Public transport investment and residential property values in Helsinki. Scandinavian Housing and Planning Research, 9(4), 217-229. doi: 10.1080/02815739208730308

47. Landis, J., Guhathakurta, S. \& Zhang, M. (1995). Capitalization of Transit Investments into SingleFamily Home Prices: A Comparative Analysis of Five California Rail Transit Systems. Retrieved from http://www.reconnectingamerica.org/assets/Uploads/bestpractice125.pdf

48. Lean, W., \& Goodall, B. (1977). Aspects of land economics. London: Estates Gazette.

49. LeSage, J. P. \& Pace, R. K. (2009). Introduction to Spatial Econometrics. Boca Raton: CRC Press.

50. LeSage, J. P. (1999, October). Applied Econometrics Using MATLAB. Retrieved from https://www.spatial-econometrics.com/html/mbook.pdf

51. Lewis-Workman, S., \& Brod, D. (1997). Measuring the Neighborhood Benefits of Rail Transit Accessibility. Transportation Research Record: Journal of the Transportation Research Board, 1576, 147-153. doi: 10.3141/1576-19

52. Li, W., \& Saphores, J.-D. (2011). A Spatial Hedonic Analysis of the Value of Urban Land Cover in the Multifamily Housing Market in Los Angeles, CA. Urban Studies, 49(12), 2597-2615. doi:

$10.1177 / 0042098011429486$ 
53. Mathur, S., \& Ferrell, C. (2013). Measuring the impact of sub-urban transit-oriented developments on single-family home values. Transportation Research Part A: Policy and Practice, 47, 42-55. doi: 10.1016/j.tra.2012.10.014

54. Mejia-Dorantes, L., \& Lucas, K. (2014). Public transport investment and local regeneration: A comparison of London's Jubilee Line Extension and the Madrid Metrosur. Transport Policy, 35, 241-252. doi: 10.1016/j.tranpol.2014.05.020

55. Mills, E. S. (1967). An Aggregate Model of Resource Allocation in a Metropolitan Area. The American Economic Review, 5(7), 197-210.

56. Mohammad, S. I., Graham, D. J., Melo, P. C., \& Anderson, R. J. (2013). A meta-analysis of the impact of rail projects on land and property values. Transportation Research Part A: Policy and Practice, 50, 158-170. doi: 10.1016/j.tra.2013.01.013

57. Mulley, C. (2013). Accessibility and Residential Land Value Uplift: Identifying Spatial Variations in the Accessibility Impacts of a Bus Transitway. Urban Studies, 51(8), 1707-1724. doi: $10.1177 / 0042098013499082$

58. Muth, R. F. (1975). Cities and Housing: The Spatial Pattern of Urban Residential Land Use. Chicago: The University of Chicago Press.

59. Nelson, A. (1999). Transit Stations and Commercial Property Values: A Case Study with Policy and Land-Use Implications. Journal of Public Transportation, 2(3), 77-95. doi: 10.5038/23750901.2.3.4

60. Nelson, A., \& McCleskey, S. (1992). Elevated Rapid Rail Transit Station Price Impacts on Single Family Residential Neighborhoods. Transportation Research Board, 1359, 127-132.

61. Newman, P., Kenworthy, J., \& Glazebrook, G. (2013). Peak Car Use and the Rise of Global Rail: Why This Is Happening and What It Means for Large and Small Cities. Journal of Transportation Technologies, 03(04), 272-287. doi: 10.4236/jtts.2013.34029

62. Pan, Q. (2012). The impacts of an urban light rail system on residential property values: a case study of the Houston METRORail transit line. Transportation Planning and Technology, 36(2), 145-169. doi: 10.1080/03081060.2012.739311

63. Pan, Q. (2012). The impacts of an urban light rail system on residential property values: a case study of the Houston METRORail transit line. Transportation Planning and Technology, 36(2), 145-169. doi: 10.1080/03081060.2012.739311

64. Pan, Q., Pan, H., Zhang, M., \& Zhong, B. (2014). Effects of Rail Transit on Residential Property Values. Transportation Research Record: Journal of the Transportation Research Board, 2453(1), 118127. doi: $10.3141 / 2453-15$

65. Redfearn, C. L. (2009). How informative are average effects? Hedonic regression and amenity capitalization in complex urban housing markets. Regional Science and Urban Economics, 39(3), 297-306. doi: 10.1016/j.regsciurbeco.2008.11.001

66. Rewers, J. M. (2009). Identifying the impacts of light rail station location on residential property values in the city of Sacramento (Master's thesis). Retrieved from https://www.csus.edu/ppa/thesis-project/bank/2009/Rewers.pdf

67. Ryan, S. (2005). The Value of Access to Highways and Light Rail Transit: Evidence for Industrial and Office Firms. Urban Studies, 42(4), 751-764. doi: 10.1080/00420980500060350

68. Seo, K. (2016). Impacts of Transportation Investment on Real Property Values: An Analysis with Spatial Hedonic Price Models (Doctoral dissertation). Retrieved from https://repository.asu.edu/attachments/170627/content/Seo_asu_0010E_16063.pdf

69. Seo, K., Golub, A., \& Kuby, M. (2014). Combined impacts of highways and light rail transit on residential property values: a spatial hedonic price model for Phoenix, Arizona. Journal of Transport Geography, 41, 53-62. doi: 10.1016/j.jtrangeo.2014.08.003 
70. Vessali, K. V. (1996). Land Use Impacts of Rapid Transit: A Review of Empirical Literature. Berkeley Planning Journal, 11(1), 71-105.

71. Voith, R. (1991). Transportation, Sorting and House Values. Real Estate Economics, 19(2), 117-137. doi: 10.1111/1540-6229.00545

72. Von Thunen, J. H. (1966). The Isolated State. Oxford: Pergamon Press.

73. Wang, Y., Feng, S., Deng, Z., \& Cheng, S. (2016). Transit premium and rent segmentation: A spatial quantile hedonic analysis of Shanghai Metro. Transport Policy, 51, 61-69. doi: 10.1016/j.tranpol.2016.04.016

74. Wang, Z. (2016). The Impact of Light Rail Transit-Oriented Development on Residential Property Value in Seattle, WA (Master's thesis). Retrieved from https://digital.lib.washington.edu/researchworks/bitstream/handle/1773/37259/Wang_wash ington_02500_16295.pdf?sequence=1

75. Weber, A. \& Friedrich, C. J. (1929). Theory of the Location of Industries. Chicago: University Press.

76. Weinberger, R. R. (2001). Light Rail Proximity: Benefit or Detriment in the Case of Santa Clara County, California? Transportation Research Record: Journal of the Transportation Research Board, 1747(1), 104-113. doi: 10.3141/1747-13

77. Weinstein, B. L. \& Clower, T. L. (1999). The Initial Economic Impacts of the DART LRT system. Retrieved from https://digital.library.unt.edu/ark:/67531/metadc30378/m2/1/high_res_d/Clower-1999Initial_Economic_Impacts_DART_LRT.pdf

78. Xu, T., \& Zhang, M. (2016). Tailoring empirical research on transit access premiums for planning applications. Transport Policy, 51, 49-60. doi: 10.1016/j.tranpol.2016.03.003

79. Zhang, M., Meng, X., Wang, L., \& Xu, T. (2014). Transit development shaping urbanization: Evidence from the housing market in Beijing. Habitat International, 44, 545-554. doi: 10.1016/j.habitatint.2014.10.012

80. Zhong, H., \& Li, W. (2016). Rail transit investment and property values: An old tale retold. Transport Policy, 51, 33-48. doi: 10.1016/j.tranpol.2016.05.007 